AGRITECH, Vol. 37, No. 2, Mei 2017, Hal. 121-131

DOI: http://doi.org/10.22146/agritech.10793

ISSN 0216-0455 (Print), ISSN 2527-3825 (Online)

Tersedia online di https://jurnal.ugm.ac.id/agritech/

\title{
Gel Glukomanan Porang-Xantan dan Kestabilannya Setelah Penyimpanan Dingin dan Beku
}

\author{
Porang Glucomannan-Xanthan Gel and Its Stability after Chilled and Frozen Storage \\ Anny Yanuriati ${ }^{1,2}$, Djagal Wiseso Marseno ${ }^{2}$, R. Rochmadi ${ }^{3}$, Eni Harmayani ${ }^{2}$ \\ 'Program Studi Teknologi Hasil Pertanian, Fakultas Pertanian, Universitas Sriwijaya, \\ J1. Raya Palembang-Prabumulih Km. 32, Indralaya, Ogan Ilir, Sumatera Selatan 30662, Indonesia \\ ${ }^{2}$ Program Studi Ilmu Pangan, Fakultas Teknologi Pertanian, Universitas Gadjah Mada, \\ Jl. Flora No. 1 Bulaksumur, Yogyakarta 55281, Indonesia \\ ${ }^{3}$ Jurusan Teknik Kimia, Fakultas Teknik, Universitas Gadjah Mada, Jl. Grafika No. 2, Yogyakarta 55281, Indonesia \\ Email: annyyanuriati@yahoo.com
}

Submisi: 28 April 2016; Penerimaan: 24 Juni 2016

\begin{abstract}
ABSTRAK
Penelitian ini bertujuan untuk menentukan proporsi komposit glukomanan porang dan xantan (GP-X) yang bersinergi optimal dalam pembentukan gel yang stabil setelah penyimpanan dingin dan beku. Sol glukomanan porang $1 \%$ dan sol xantan 1\% dicampur dengan proporsi GP-X 20/40; 40/60; 50/50; 60/40; dan 80/20. Campuran tersebut dipanaskan pada suhu $90-95{ }^{\circ} \mathrm{C}$ selama 45 menit disertai pengadukan selama 5 menit, dicetak, didinginkan dan disimpan pada suhu dingin $\left(5^{\circ} \mathrm{C}\right)$ dan beku $\left(-8^{\circ} \mathrm{C}\right)$ selama 24 hari. Profil tekstur, water binding capacity (WBC), dan sineresis dianalisis di awal dan setelah penyimpanan. Morfologi gel komposit sebelum penyimpanan dan morfologi gel yang paling optimum setelah penyimpanan dianalisis dengan Scanning Electron Microscope (SEM). Sinergi pembentukan gel komposit GP-X paling optimal didapatkan dengan ratio 20/80. Asosiasi intermolekul GP-X pada proporsi tersebut membentuk zona hubung yang panjang dan densitas tinggi sehingga menghasilkan hardness, chewiness, dan gumminess paling tinggi dengan derajat deformasi dan sineresis paling rendah serta daya kohesif yang sedang. Meskipun belum mengalami sineresis selama 24 hari penyimpanan dingin, pengecilan ukuran jaringan tiga dimensi (pori) gel komposit tersebut menunjukkan gel mulai kontraksi dan mengalami penurunan mutu dengan indikasi penurunan daya kohesif, chewiness, hardness, dan gumminess. Peningkatan WBC pada proporsi yang lebih tinggi menyebabkan gel nampak lebih stabil pada penyimpanan beku dibandingkan dengan penyimpanan dingin. Pembesaran pori gel akibat pengembangan volume air yang terperangkap selama pembentukan kristal es menyebabkan peningkatan sineresis, pemadatan gel, dan peningkatan hardness, chewiness, gumminess, dan persentase deformasi.
\end{abstract}

Kata kunci: Gel; glukomanan; porang (Amorphophallus muelleri Blume); sinergi; xantan

\begin{abstract}
The objectives of this research were to find the porang glucomannan-xanthan optimum ratio on composite gelation and its stability after chilled and frozen storage. Porang glucomannan sol was mixed with xanthan sol in ratio 20/40; 40/60; 50/50; 60/40 and 80/20. The composites were heated for 45 minutes at $90{ }^{\circ} \mathrm{C}$ with agitation for 5 minutes, molded, tempered, and stored at $5{ }^{\circ} \mathrm{C}$ dan $-8{ }^{\circ} \mathrm{C}$ for 24 days. Before dan after storage, the texture profile, WBC and sineresis of the gel were analyzed. The composite gel microstructure was analyzed using SEM. The composite gel with ratio $20 / 80$ had the optimum interaction synergy on gelation and stability. The GP-X intermolecular association resulted in long high density junction zones which had highest hardness, chewiness and gumminess with the smallest deformation
\end{abstract}


degree and sineresis as well as medium cohesiveness. Despite of no sineresis after chilled storage, the smaller gel pores indicated that the composite gel began to contract and degrade which resulted in cohesiveness, chewinees, hardness and gumminess decrease. The WBC increase on the higher GP-X ratio composite gel made the gel to be more stable in frozen storage compared to chilled storage. However, the bigger gel pores from entrapped water volume increasing during frozen storage crystal ice formation resulted in sineresis increase. The gel became more compact with higher cohesiveness, hardness, chewiness, gumminess and deformation degree.

Keywords: Gel; glucomannan; porang (Amorphophallus muelleri Blume); synergy; xanthan

\section{PENDAHULUAN}

Porang atau iles kuning (Amorphophallus muelleri Blume) merupakan salah satu tanaman jenis Amorphophallus indigenous Indonesia yang umbinya sangat potensial sebagai sumber glukomanan. Pada industri pangan, glukomanan dimanfaatkan untuk pengental, pembentuk gel, perbaikan tekstur, pengikat air, pengganti lemak (Takigami, 2000), penstabil dan pengemulsi (Zhang, dkk., 2005) serta edible film (Cheng dkk., 2002; 2007).

Salah satu produk pangan dari glukomanan adalah hidrokoloid gel. Glukomanan juga dapat digunakan sebagai bahan tambahan atau substitusi untuk produk pangan, terutama untuk pengembangan produk restrukturisasi. Glukomanan dapat memperbaiki tekstur dan sifat reologi produk makanan karena memiliki kemampuan mengembang, membentuk gel, mengental, mengabsorbsi dan mengikat air (Behera dan Ray, 2016). Pada produk restrukturisasi, hidrokoloid glukomanan dapat dimanfaaatkan sebagai binder protein (Ramirez dkk., 2011; Chua dkk., 2010) dan pengganti lemak (Jimenez-Colmenero., 2013) sehingga dapat menghasilkan produk pangan yang rendah lemak (JimenezColmenero dkk., 2012; Ramirez dkk. 2011) dan juga rendah garam (Ramirez dkk. 2011). Selain itu, sebagai serat pangan larut air (prebiotik) (Al-Ghazzewi dkk., 2007), glukomanan sangat bermanfaat bagi kesehatan, dapat menurunkan kolesterol, trigliserida dan glukosa darah (Takigami, 2000; Tester dan Al-Ghazzewi, 2009), juga sebagai sumber energi jaringan kolon dan menstimulasi pertumbuhan bakteri BAL, mengurangi $\mathrm{pH}$ kolon, dan mereduksi akumulasi dan pertumbuhan mikrobia pathogen (Tester dan Al-Ghazzewi, 2013), sehingga dapat menurunkan berat badan, mencegah kanker kolon, meningkatkan fungsi pencernaan serta fungsi imun (Tester dan Al-Ghazzewi, 2009).

Glukomanan membentuk heat set gel (Zhang dkk., 2011) bila ditambahkan dengan alkali (Herranz dkk., 2013; Lin dan Huang, 2008; Zhang dkk., 2011) atau garam (Chen dkk., 2011; Yin dkk., 2008). Namun proses ini akan menghasilkan gel yang sangat alkali karena $\mathrm{pH}$ optimal pembentukan gel sekitar 11,3 -12,6 (Kohyama dan Nishinari 1997), sehingga diperlukan proses penetralan (Herranz dkk., 2013) agar tidak mengganggu flavour dan rasa produk (Hosogoe dkk., 1992). Gel yang dibentuk dengan alkali juga tidak memiliki efek kesehatan seperti yang diuraikan sebelumnya (Takigami, 2000).

Alternatif lain, pembentukan gel glukomanan pada kondisi netral dapat dilakukan dengan pencampuran hidrokoloid yang bersinergi dengan glukomanan. Glukomanan konjac (GK) bersinergi dengan xantan membentuk gel pada kondisi netral sampai alkali (Fitzpatrick dkk., 2013; Fitzsimons dkk., 2008; Liang dkk., 2011; Mao dkk., 2012; Paradossi dkk., 2002). Pada kondisi netral, GK dapat bersinergi membentuk gel paling kuat dengan xantan dibandingkan dengan hidrokoloid lain, seperti guar gum, karagenan, sodium alginat, sodium karboksil selulosa, metil selulosa, hidroksi etil selulosa, dan gum arabik (Liang dkk., 2011). Mekanisme pembentukan gel pada glukomanan konjac sangat dipengaruhi oleh berat molekul (Shen dkk., 2009) dan derajat asetilasi (Gao dan Nishinari, 2004; Nishinari dan Takahashi, 2003), konsentrasi, suhu dan konsentrasi alkali (Alonso-Sande dkk., 2009; Herranz dkk., 2013). Penelitian sinergisme glukomanan porang, hasil isolasi langsung dari porang segar yang dikompositkan dengan xantan dalam pembentukan gel dan kestabilannya selama penyimpanan belum dilakukan. Penelitian ini bertujuan untuk menentukan proporsi campuran hidrokoloid GP-X optimal yang bersinergi optimal menghasilkan gel komposit yang stabil setelah penyimpanan dingin atau freezing-thawing.

\section{METODE PENELITIAN}

\section{Bahan dan Alat}

Bahan penelitian ini adalah granula glukomanan hasil isolasi dari umbi porang segar, xantan berukuran 80 mesh (food grade) diperoleh dari Qingdao ICD Biochemistry Co. Ltd, China, ethanol 96\%, dan akuademin. Sedangkan alat yang digunakan adalah agitator, water bath, Scanning Electrone Microscope (SEM) Merk FEI tipe S50, EDAX AMETEK, USA; Texture Profile Analyzer (TPA) Brookfield model LFRA, Middleboro, USA. dengan texture expert software, sentrifugator, oven, neraca analitik, labu ukur, gelas ukur dan gelas beaker. 


\section{Preparasi Gel}

Glukomanan diisolasi langsung dari umbi porang segar dengan cara penggilingan dan penyaringan berulang sampai $7 \mathrm{x}$ dan dikeringkan pada suhu $45^{\circ} \mathrm{C}$ (Yanuriati dkk., 2017). Granula glukomanan 1\% (berat molekul rata-rata berat 1,27 $\mathrm{x} 10^{6}$ ) atau xantan 1\% masing-masing dilarutkan dalam akuademin (sol) dan dicampur dengan proporsi 20/80, 40/60, 50/50, 60/40, dan 80/20. Sol dipanaskan pada suhu $95{ }^{\circ} \mathrm{C}$ selama 45 menit disertai pengadukan selama 5 menit dan dimasukkan dalam cetakan berupa gelas silinder berdiameter dan tinggi $4 \mathrm{~cm} \times 4,5 \mathrm{~cm}$. Setelah dingin disimpan pada suhu $5{ }^{\circ} \mathrm{C}$ (dingin) dan $-8{ }^{\circ} \mathrm{C}$ (beku) selama 24 hari (Akesowan, 2012). Sebelum dan setelah penyimpanan, profil tekstur, WBC, sineresis, dan morfologi gel serta perubahannya dianalisis.

\section{Profil Tektur}

Gel dikeluarkan dari cetakan dan dianalisa dengan TPA. Tipe probe yang digunakan adalah bentuk bola berdiameter $2,54 \mathrm{~cm}$. Gel berbentuk silinder berdiameter dan tinggi $4 \mathrm{x}$ $4,5 \mathrm{~cm}$ ditekan dengan probe mencapai $40 \%$ dari tingginya. Beban sebesar $20 \mathrm{~g}$ diberikan dengan kecepatan $0,5 \mathrm{~mm} / \mathrm{s}$. Parameter yang dianalisa adalah cohesiveness $(\mathrm{ch})=$ proporsi area positip tekanan selama siklus kompresi kedua terhadap area positip tekanan selama siklus kompresi pertama. Springiness ( $\mathrm{sp})$ merupakan jarak (mm) sampel kembali ke bentuk semula setelah penekanan pertama, hardness (hd) merupakan gaya puncak yang dibutuhkan untuk penekanan pertama (g), chewiness adalah hd $\mathrm{x}$ ch $\mathrm{x}$ sp $(\mathrm{N} \times \mathrm{mm})$, gumminess adalah hd $\mathrm{x}$ ch, dan persen deformasi.

\section{Water Binding Capacity}

Water binding capacity (WBC) diukur berdasarkan metode Jimenez-Colmenero dkk. (2013). Gel dipotong bentuk kotak ( $2 \mathrm{~g}$ ) dan disimpan pada suhu dingin dan beku. Setelah 24 hari, gel dikeluarkan dan dibiarkan di suhu ruang selama beberapa jam. Gel selanjutnya dibungkus dengan kertas filter (whatman 1) dan diletakkan dalam tabung sentrifus. Sampel kemudian disentrifus pada $4000 \mathrm{rpm}$ selama 10 menit. Hasilnya diekspresikan sebagai \% air yang tertahan di sampel per $100 \mathrm{~g}$ air yang ada pada sampel sebelum disentrifus (\%). Tingginya WBC mengidentifikasikan sedikitnya air yang dibebaskan selama sentrifus.

\section{Sineresis}

Sineresis gel akibat pendinginan dan pembekuan ditentukan berdasarkan perbedaan berat (\%) antara sampel awal dan sampel yang disimpan. Pada sampel beku, perbedaan berat antara gel yang dibekukan dengan gel yang telah dicairkan (thawing) menunjukkan stabilitas freezing/ thawing yang diekspresikan sebagai persentase sineresis. Sineresis yang lebih tinggi berarti lebih banyak air yang dibebaskan dan rendahnya stabilitas gel terhadap dingin atau freezing/thawing (Lin dkk., 2008).

\section{Morfologi Gel}

Morfologi gel yang bersinergi paling optimum dianalisa dengan SEM. Gel diliofilisasi dengan freeze drier dan dipotong dengan silet merk goal. Potongan selanjutnya ditempatkan pada lempengan karbon, divakum, dan dilapisi dengan emas, serta diobservasi dengan SEM (Tatirat dkk., 2011).

\section{Pengolahan Data dengan Uji Statistik SPSS}

Data dianalisis dengan menggunakan ANOVA Rancangan Acak Lengkap (RAL) Faktorial. Perbedaannya dilakukan dengan Uji Duncan.

\section{HASIL DAN PEMBAHASAN}

\section{Cohesiveness}

Cohesiveness merupakan daya kohesif yang menggambarkan kekuatan dari ikatan-ikatan internal penyusun gel (deMan, 2000). Peningkatan daya kohesif secara signifikan terjadi pada gel komposit GP-X proporsi 50/50 sampai 60/40 (Gambar 1). Penambahan proporsi GP-X menjadi 80/20 menurunkan daya kohesif secara signifikan (Gambar 1).

Penambahan proporsi glukomanan sampai 60/40 meningkatkan asosiasi antar molekul xantan dengan glukomanan dan xantan dengan xantan, yang ditunjukkan dengan jumlah zona hubung yang semakin banyak (Gambar 2A - 2D). Peningkatan jumlah zona hubung dengan jarak lebih pendek dan densitas lebih rendah ini menghasilkan gel yang memiliki jumlah matriks 3 dimensi (pori) lebih banyak dengan ukuran semakin kecil, tidak homogen dan cenderung berbentuk bulat. Perubahan ini menyebabkan peningkatan signifikan pada daya kohesif gel komposit, namun daya kohesif mengalami penurunan pada peningkatan proporsi glukomanan yang lebih besar (80/20) dan menjadi berbeda tidak nyata dibandingkan dengan daya kohesif gel komposit GP-X, baik pada proporsi 20/80 maupun 40/60. Penurunan daya kohesif ini disebabkan oleh penurunan kembali jumlah zona hubung (Gambar 2E) hasil asosiasi intermolekul xantan dan glukomanan pada proporsi glukomanan 80/20 Penambahan proporsi GP-X 80/20 menyebabkan glukomanan berlebih dan tidak berasosiasi dengan xantan, tidak membentuk gel dan tetap dalam bentuk sol yang berupa fase kontinyu (Gambar 2F). Pada proporsi 80/20, zona hubung 

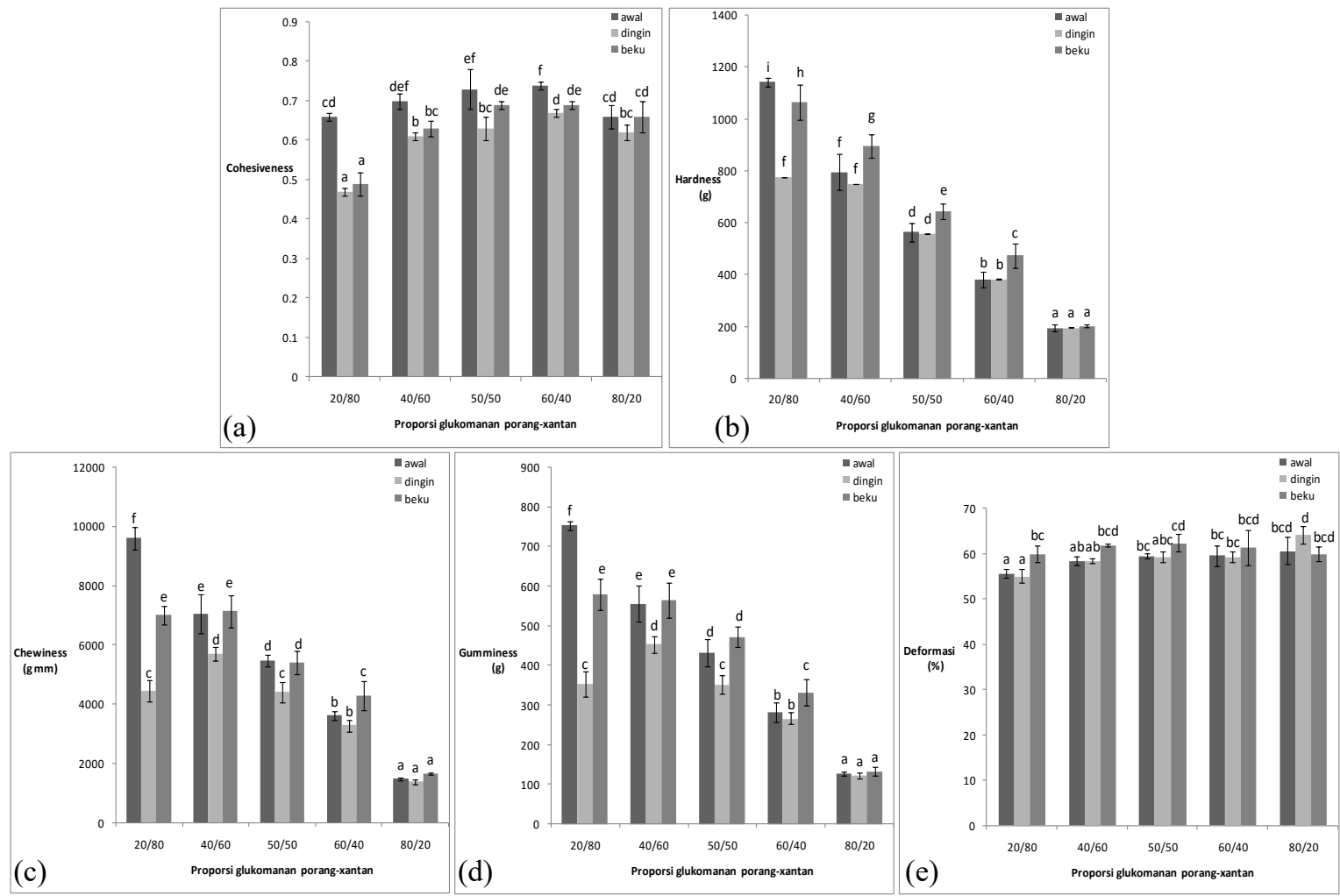

Gambar 1. Histogram perubahan profil tekstur gel komposit glukomanan porang-xantan dengan berbagai proporsi komposit sebelum dan setelah 24 hari penyimpanan dingin dan beku (a) cohesiveness, (b) hardness, (c) chewiness, (d) gummines, (e) deformasi

antar rantai berkurang dengan bentuk memanjang sehingga jumlah matriks 3 dimensi berkurang signifikan dan berukuran lebih besar. Perubahan ini menyebabkan cohesiveness gel menurun signifikan (Gambar 1).

Setelah 24 hari penyimpanan, baik pada suhu dingin maupun beku, daya kohesif gel mengalami penurunan secara signifikan. Namun, daya kohesif gel komposit penyimpanan dingin tidak berbeda nyata dengan penyimpanan beku, kecuali pada gel komposit GP-X proporsi 50/50 penyimpanan beku (Gambar 1) memiliki daya kohesif secara signifikan lebih tinggi dibandingkan pada penyimpanan dingin.

Daya kohesif gel komposit GP-X yang memiliki proporsi GP-X lebih besar mengalami penurunan lebih kecil. Fenomena ini dapat dihubungkan dengan adanya peningkatan WBC seiring dengan peningkatan proporsi glukomanan sampai 60/40. Glukomanan mampu mengabsorbsi air lebih besar dibandingkan dengan xantan. Peningkatan WBC gel komposit pada proporsi glukomanan yang lebih besar menunjukkan peningkatan ikatan hidrogen antara air dan glukomanan dan air terperangkap pada matriks gel. Volume matriks 3 dimensi lebih kecil juga menyebabkan ikatan hidrogen antara $\mathrm{OH}$ polimer dengan air lebih dekat serta air terperangkap di dalam matriks lebih stabil, sehingga penurunan cohesiveness lebih kecil saat pembekuan dibandingkan penyimpanan dingin. Air terikat tidak mengalami pengembangan volume sehingga pada penyimpanan beku lebih stabil dari penyimpanan dingin.
Penurunan cohesiveness paling besar selama penyimpanan dingin pada proporsi 20/80 diperkirakan disebabkan oleh kontraksi dan penurunan mutu karena belum mengalami peningkatan sineresis signifikan, meskipun WBCnya rendah. Hasil pengamatan menunjukkan bahwa xantan lebih mudah rusak dibandingkan glukomanan, sehingga pada proporsi glukomanan yang besar, penurunan daya kohesif menjadi lebih kecil.

\section{Springiness}

Penambahan glukomanan sampai proporsi 60/40 tidak berpengaruh nyata terhadap springiness gel komposit. Springiness mulai mengalami penurunan secara signifikan pada proporsi GP-X 80/20 (Tabel 1).

Penurunan springiness tersebut dapat disebabkan oleh kelebihan proporsi glukomanan menghasilkan glukomanan yang tidak berinteraksi dengan xantan dan tetap dalam kondisi bebas berbentuk sol (Shen dkk., 2009) serta dapat melemahkan asosiasi intermolekuler glukomanan dan xantan sehingga springiness menurun. Penurunan intermolekuler GP-X menyebabkan zona hubung berkurang dan jaringan 3 dimensi terbentuk lebih sedikit dan cenderung memanjang.

Glukomanan $1 \%$ sangat kental dan tidak dapat membentuk gel. Molekul glukomanan yang berlebih akan 

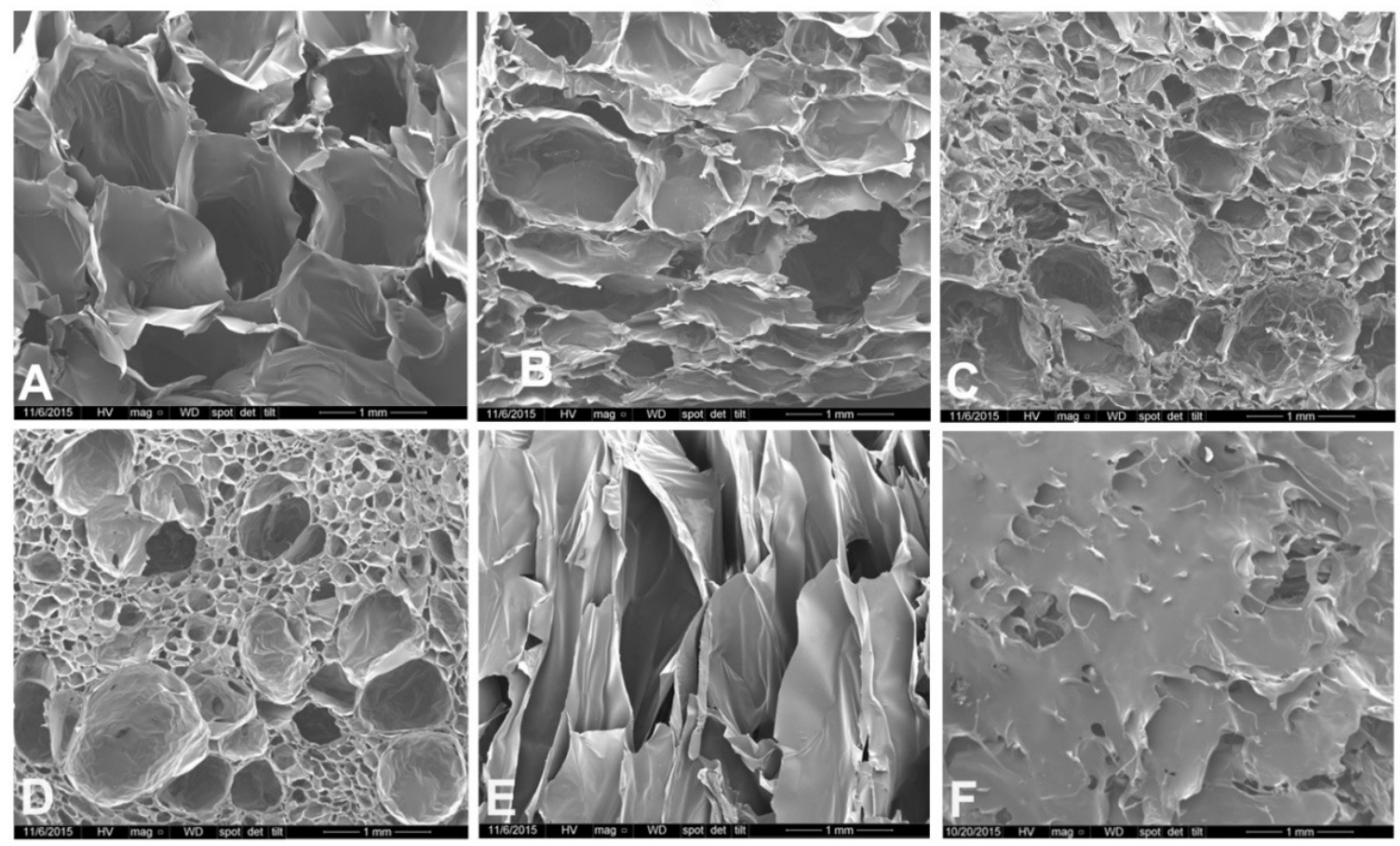

Gambar 2. Morfologi gel komposit glukomanan xantan dengan proporsi 20/80 (A), 40/60 (B), 50/50 (C), 60/40 (D), 80/20 (E) dan sol glukomanan yang dipanaskan (F) dengan pembesaran 70x

bebas dan tumpang tindih (overlapping) dan entanglement (Ojima dkk., 2009; He dkk., 2012) serta self-association di larutan aqueous (Liang dkk., 2011), namun tetap dalam bentuk sol viskous yang tidak dapat membentuk gel. Zona hubung menurun menyebabkan jumlah jaringan 3 dimensi menurun karena sol cenderung membentuk jaringan yang kontinyu (Gambar 2F). Brenner dkk.(2015) juga menemukan hal yang sama terjadi pada gel komposit glukomanan dan karagenan bila glukomanan dalam jumlah berlebih.

Tabel 1. WBC gel komposit glukomanan porang dengan xanthan selama 24 hari penyimpanan

\begin{tabular}{llll}
\hline Perlakuan & & Springiness & WBC (\%) \\
\hline Proporsi GP-X & $20 / 80$ & $12,53 \pm 0,18^{\mathrm{b}}$ & $55,98 \pm 2,57^{\mathrm{ab}}$ \\
& $40 / 60$ & $12,62 \pm 0,07^{\mathrm{b}}$ & $58,67 \pm 4,63^{\mathrm{bc}}$ \\
& $50 / 50$ & $12,70 \pm 0,39^{\mathrm{b}}$ & $60,00 \pm 3,17^{\mathrm{c}}$ \\
& $60 / 40$ & $12,76 \pm 0,23^{\mathrm{b}}$ & $59,13 \pm 3,75^{\mathrm{c}}$ \\
& $80 / 20$ & $11,68 \pm 0,47^{\mathrm{a}}$ & $55,70 \pm 3,02^{\mathrm{a}}$ \\
Penyimpanan & Awal & NS & $60,54 \pm 1,60^{\mathrm{b}}$ \\
& 24 hari suhu dingin & NS & $57,33 \pm 1,99^{\mathrm{a}}$ \\
& 24 hari suhu beku & NS & $55,81 \pm 0,75^{\mathrm{a}}$ \\
\hline
\end{tabular}

Keterangan:

Huruf yang berbeda di belakang angka menunjukkan perbedaan yang nyata. $\mathrm{ns}=$ non significant

\section{Hardness}

Hardness paling tinggi dimiliki oleh gel komposit GP-X pada proporsi 20/80 (Gambar 1). Proporsi glukomanan porang yang diperlukan pada proses sinergi pembentukan gel komposit GP-X pada penelitian ini lebih kecil (20/80) dibandingkan dengan proporsi yang dilaporkan Akesowan $(2002 ; 2012)$ sebesar $60 / 40$. Proporsi glukomanan yang lebih besar pada penelitiannya dapat disebabkan oleh berat molekul glukomanan porang yang digunakan lebih kecil sehingga membutuhkan jumlah proporsi lebih banyak. Glukomanan $1 \%$ yang digunakannya memiliki viskositas lebih rendah sekitar 13.500 cps pada kecepatan 100 rpm, sedangkan viskositas $1 \%$ glukomanan porang pada penelitian ini sangat tinggi sehingga tidak dapat diukur dengan kecepatan 100 rpm, tetapi baru dapat diukur dengan kecepatan yang lebih rendah $<50 \mathrm{rpm}$. Menurut Ojima dkk. (2009), viskositas yang tinggi bisa menunjukkan bahwa molekul glukomanan tersebut memiliki berat molekul yang tinggi. Berat molekul glukomanan yang digunakan pada penelitian ini 1,2 x 106 (Yanuriati dkk., 2017). Shen dkk. (2009), jumlah rantairantai aktif elastis dan rantai panjang aktif dalam jaringan gel yang berhubungan dengan peningkatan zona hubung berkorelasi dengan peningkatan berat molekul glukomanan sampai nilai tertentu dan menyebabkan jumlah zona hubung antar rantai molekul glukomanan dengan xantan lebih banyak dan kuat. Peningkatan kekuatan gel seiring dengan berat 
molekul glukomanan yang tinggi ini menyebabkan proporsi glukomanan yang dibutuhkan lebih rendah.

Namun, peningkatan proporsi glukomanan yang lebih besar menyebabkan penurunan hardness gel komposit glukomanan xantan secara signifikan dengan penurunan yang semakin besar pada proporsi glukomanan yang lebih tinggi (Gambar 1). Peningkatan daya kohesif pada gel komposit dengan proporsi glukomanan lebih besar tidak diikuti dengan peningkatan pada hardness. Hardness gel komposit cenderung menurun seiring dengan peningkatan proporsi glukomanan xantan. Penurunan hardness yang semakin besar pada proporsi glukomanan yang lebih tinggi (Gambar 1) dapat dihubungkan dengan hasil pengamatan morfologi gel (Gambar 2A-E). Pada gel komposit 40/60, untaian-untaian molekul membentuk asosiasi menjadi zona hubung yang menghasilkan struktur 3 dimensi dengan jumlah semakin banyak tetapi ukuran lebih kecil dan lebih pendek. Penambahan proporsi GP-X sampai 60/40 akan membentuk struktur 3 dimensi yang lebih banyak dengan ukuran lebih kecil, zona hubung lebih pendek dan densitas yang lebih rendah. Meningkatnya zona hubung yang lebih pendek dengan densitas yang lebih rendah pada gel komposit GP-X dengan proporsi glukomanan yang lebih besar diperkirakan sebagai penyebab penurunan hardness gel komposit pada proporsi glukomanan yang lebih tinggi. Zona hubung yang banyak namun pendek dan densitas rendah memiliki kekuatan yang lebih rendah dibandingkan dengan zona penghubung yang lebih sedikit, lebih panjang dan padat.

Setelah 24 hari penyimpanan dingin, hardness semua gel komposit masih stabil, kecuali pada proporsi 20/80 hardness mengalami penurunan secara signifikan (Gambar 1). Namun penurunan hardness pada penyimpanan dingin tidak diikuti dengan peningkatan sineresis yang signifikan. Peningkatan sineresis secara signifikan baru terjadi pada gel komposit proporsi GP-X $\geq 40 / 60$. Selain WBC awal yang lebih rendah (Tabel 1), selama 24 hari penyimpanan dingin, gel dapat mengalami kontraksi yang dapat dilihat dengan jaringan 3 dimensi gel komposit mengecil (Gambar 3B). Kontraksi ini dapat mengkontribusi penurunan hardness gel komposit proporsi 20/80 penyimpanan dingin. Selain itu, hasil pengamatan menunjukkan sol xantan lebih cepat rusak dibandingkan dengan glukomanan sehingga proporsi xantan yang lebih banyak menyebabkan penurunan mutu gel lebih cepat dibandingkan proporsi xantan yang lebih rendah. Penurunan hardness pada gel komposit proporsi 20/80 setelah 24 hari penyimpanan dingin ini diduga mulai mengalami penurunan mutu. Penurunan mutu pada penyimpanan dingin lebih cepat dibandingkan dengan penyimpanan suhu beku.

Setelah 24 hari penyimpanan beku, hardness gel komposit proporsi GP-X 20/80 juga mengalami penurunan signifikan, namun penurunannya secara signifikan lebih kecil dibandingkan pada penyimpanan dingin. Sedangkan hardness proporsi $\geq 40 / 60$ sampai $60 / 40$ cenderung meningkat, meskipun demikian masih lebih rendah dibandingkan dengan hardness gel komposit proporsi 20/80. Hardness gel komposit proporsi 80/20 mengalami penurunan paling besar, selanjutnya tetap stabil selama penyimpanan. Zona hubung yang lebih banyak, namun pendek dan densitas rendah memiliki kekuatan lebih rendah dibandingkan dengan zona hubung yang lebih panjang, homogen dan padat. Peningkatan WBC gel komposit proporsi 40/60, 50/50 dan 60/40 setelah 24 hari penyimpanan beku menunjukkan ikatan antara polimer dengan air meningkat dan stabil selama pembekuan, sehingga hardness lebih stabil pada penyimpanan beku (Gambar 1) dibandingkan penyimpanan dingin. Selain itu, air yang terperangkap dalam matriks gel selama pembekuan mengalami pengembangan volume, memperbesar pori (Gambar 3C) dan meningkatkan sineresis. Setelah freezing/ thawing, peningkatan sineresis menyebabkan gel menjadi lebih kompak dan padat sehingga hardness nampak meningkat (Gambar 1 dan Tabel 2). Setelah mengalami penurunan yang sangat signifikan, hardness gel komposit 80/20 cenderung stabil baik penyimpanan beku maupun penyimpanan dingin. Kestabilan ini dapat dikorelasikan dengan WBC rendah dan sineresis yang paling rendah. Kelebihan proporsi glukomanan pada proporsi $80 / 20$ tidak membentuk gel dan menurunkan jumlah jaringan 3 dimensi dengan volume lebih besar dan bentuk memanjang (Gambar 2E). Penurunan tersebut menyebabkan jumlah air terperangkap dan WBC juga rendah (Tabel 1) serta sineresis paling rendah (Tabel 2) sehingga hardness dapat stabil (Gambar 1).

\section{Chewiness}

Chewiness paling tinggi terdapat pada gel komposit dengan proporsi GP-X 20/80 (Gambar 1). Asosiasi glukomanan dan xantan pada proporsi tersebut menghasilkan zona hubung yang lebih panjang, homogen dengan densitas yang paling tinggi (Gambar 2). Ikatan intermolekuler paling kuat ini mengkontribusi peningkatan chewiness. Chewiness menurun secara signifikan dengan semakin meningkatnya proporsi glukomanan (Gambar 1). Penurunan chewiness ini disebabkan oleh peningkatan asosiasi intermolekul glukomanan dan xantan dengan jumlah zona hubung dan struktur 3 dimensi lebih banyak, namun ikatan lebih pendek dan densitas lebih kecil (Gambar 1).

Selama 24 hari penyimpanan dingin, chewiness gel komposit proporsi sampai 50/50 mengalami penurunan signifikan dengan penurunan cenderung lebih besar pada gel komposit proporsi yang lebih besar. Pada proporsi glukomanan yang lebih tinggi $\geq 60 / 40$ chewiness gel komposit lebih stabil (Gambar 1). Chewiness gel komposit proporsi 80/20 paling rendah dan masih stabil selama 24 hari penyimpanan, baik pada suhu dingin maupun beku (Gambar 1). Penurunan 
chewiness selama penyimpanan dingin dapat disebabkan oleh kontraksi gel yang dapat dijelaskan dengan pengecilan pori (Gambar 3B). Penurunan chewiness yang lebih kecil pada gel proporsi GP-X yang lebih besar dapat dihubungkan dengan peningkatan WBC (Tabel 1). Peningkatan WBC mengindikasikan bahwa terjadi peningkatan ikatan hidrogen antara polimer dan air sehingga juga lebih stabil saat pembekuan, sehingga penurunan chewiness lebih rendah. Peningkatan signifikan chewiness pada proporsi $60 / 40$ setelah 24 hari penyimpanan beku disebabkan oleh WBC yang masih tinggi, namun adanya pengembangan volume air terperangkap selama pembekuan dapat memperbesar pori (Gambar 3C). Setelah freezing/thawing, gel komposit tersebut mengalami sineresis yang tinggi dan menyebabkan tekstur menjadi lebih kompak serta meningkatkan chewiness.

\section{Gumminess}

Sama halnya dengan hardness dan chewiness, gumminess tertinggi juga terdapat pada gel komposit GP-X dengan perbandingan 20/80. Gumminess mengalami penurunan signifikan dengan peningkatan proporsi glukomanan (Gambar 1). Penurunan gumminess pada gel komposit GP-X dengan peningkatan proporsi glukomanan juga berkaitan erat dengan perubahan zona hubung yang semula panjang menjadi zona hubung yang lebih banyak, namun ikatannya lebih pendek dan densitas menurun (Gambar 2).

Setelah 24 hari penyimpanan dingin, gumminess gel komposit GP-X cenderung mengalami penurunan signifikan dengan penurunan yang lebih kecil pada proporsi glukomanan yang lebih besar, namun setelah mencapai proporsi GP-X $\geq 60 / 40$, gumminess gel komposit menjadi lebih stabil. Penurunan gumminess yang terjadi pada gel komposit proporsi 20/80 setelah 24 hari penyimpanan dingin cenderung disebabkan oleh kontraksi gel dan penurunan mutu yang mulai terjadi setelah 24 hari penyimpanan dingin.

Sedangkan pada penyimpanan beku, gumminess cenderung stabil kecuali pada proporsi 20/80. Kestabilan ini dapat dihubungkan dengan peningkatan WBC pada gel yang memiliki proporsi GP-X lebih besar. Peningkatan WBC mengindikasikan bahwa ikatan hidrogen antara polimer dengan air meningkat dan stabil pada penyimpanan beku sehingga gumminess cenderung stabil. Namun, pada peningkatan proporsi GP-X 60/40, gumminess mengalami peningkatan signifikan. Pengembangan volume air selama pembekuan meningkatkan sineresis pada gel komposit, menyebabkan tekstur menjadi kompak dan padat sehingga meningkatkan gumminess.

\section{Persen Deformasi}

Persen deformasi paling rendah terjadi pada gel komposit dengan proporsi glukomanan 20/80 dan cenderung stabil setelah 24 hari penyimpanan dingin, namun meningkat signifikan setelah 24 hari penyimpanan beku (Gambar 1). Peningkatan proporsi glukomanan pada gel komposit menyebabkan peningkatan persen deformasi secara signifikan. Peningkatan proporsi glukomanan menyebabkan jumlah zona hubung meningkat, namun densitasnya lebih rendah sehingga persen deformasi meningkat. Peningkatan persen deformasi setelah 24 hari penyimpanan beku dapat dihubungkan dengan pengembangan volume air terperangkap selama pembekuan dapat menyebabkan peningkatan sineresis setelah freezing/ thawing. Sineresis yang tinggi menyebabkan gel menjadi lebih kompak dan meningkatkan persen deformasi.

\section{Water Binding Capacity}

Water binding capacity gel komposit cenderung meningkat signifikan dengan meningkatnya proporsi GP-X sampai 60/40. Namun setelah proporsi glukomanan dan xantan 80/20, WBC mengalami penurunan signifikan dan berbeda tidak nyata dengan gel komposit proporsi 20/80 (Gambar 1). Glukomanan mampu mengabsorbsi air lebih besar dari xantan. Menurut Wen dkk. (2008) dan Maeda dkk. (1980), $1 \mathrm{~g}$ GK dapat mengabsorsi sampai $200 \mathrm{ml}$ air. Peningkatan WBC gel komposit mengindikasikan terjadinya peningkatan ikatan hidrogen antara air dengan polimer glukomanan. Perubahan volume jaringan 3 dimensi menjadi lebih kecil pada proporsi yang lebih besar menyebabkan air terperangkap lebih stabil. Namun, glukomanan yang berlebih pada proporsi 80/20 tidak berasosiasi dengan xantan pada proporsi GP-X 80/20, tetap berupa sol yang membentuk fase kontinyu dan melemahkan asosiasi intermolekuler GP-X. Jumlah zona hubung dan jaringan 3 dimensi berkurang dengan volume yang lebih besar dan bentuk memanjang. Perubahan ini mengkontribusi penurunan WBC dan air terperangkap.

Setelah 24 hari penyimpanan baik pada suhu dingin maupun suhu beku, WBC gel komposit GP-X mengalami penurunan. Tidak ada perbedaan signifikan ditemukan pada WBC gel komposit setelah penyimpanan dingin maupun beku (Tabel 1). Penyimpanan dingin dapat menyebabkan gel mengalami kontraksi yang merupakan penyusutan akibat perubahan ikatan hidrogen antara polimer dengan air dan penyusutan air terperangkap. Sedangkan selama penyimpanan beku, pengembangan volume air menjadi kristal es dapat menyebabkan pembesaran jaringan 3 dimensi (Gambar 3C) dan meningkatnya sineresis.

\section{Sineresis}

Semua gel komposit glukomanan setelah 24 hari penyimpanan dingin mengalami sineresis, kecuali gel komposit GP-X proporsi $20 / 80$ belum mengalami peningkatan signifikan (Tabel 2). Sineresis secara signifikan mulai terjadi pada gel komposit GMP proporsi $\geq 40 / 60$. 
Meskipun demikian, sineresisnya juga masih rendah $\leq 1 \%$. Sineresis gel komposit GP-X setelah 24 hari penyimpanan beku lebih besar dibandingkan dengan penyimpanan dingin. Peningkatannya secara signifikan terjadi pada gel komposit proporsi 40/60, kemudian pada proporsi lebih rendah menurun signifikan. ikatan gel juga mengalami kontraksi semakin dekat dan menyebabkan terjadinya peningkatan sineresis pada gel komposit. Peningkatan sineresis tidak berbanding terbalik dengan peningkatan WBC yang terjadi seiring dengan peningkatan proporsi glukomanan xantan sampai 60/40. Sineresis nampaknya lebih disebabkan oleh pengembangan volume air terperangkap yang terjadi selama pembekuan dan menyebabkan volume jaringan 3 dimensi membesar serta menkontribusi peningkatan sineresis. Perubahan ini diperkuat dengan peningkatan hardness, chewiness dan gumminess pada gel komposit proporsi GP-X 60/40 setelah 24 hari penyimpanan beku (Gambar 1).

Tabel 2. Sineresis gel komposit glukomanan dengan berbagai proporsi glukomanan dan xantan (GMPX) pada awal dan setelah penyimpanan dingin dan beku

\begin{tabular}{cccc}
\hline Ratio GMPX & \multicolumn{3}{c}{ Sineresis (\%) } \\
\hline & Awal & Dingin & Beku \\
$20 / 80$ & $0^{\mathrm{a}}$ & $0,67 \pm 0,06^{\mathrm{ab}}$ & $9,57 \pm 0,10^{\mathrm{d}}$ \\
$40 / 60$ & $0^{\mathrm{a}}$ & $0,99 \pm 0,01^{\mathrm{b}}$ & $12,75 \pm 0,69^{\mathrm{f}}$ \\
$50 / 50$ & $0^{\mathrm{a}}$ & $0,94 \pm 0,02^{\mathrm{b}}$ & $11,83 \pm 1,02^{\mathrm{e}}$ \\
$60 / 40$ & $0^{\mathrm{a}}$ & $0,99 \pm 0,07^{\mathrm{b}}$ & $9,93 \pm 0,93^{\mathrm{d}}$ \\
$80 / 20$ & $0^{\mathrm{a}}$ & $1,00 \pm 0,09^{\mathrm{b}}$ & $3,57 \pm 0,23^{\mathrm{c}}$ \\
\hline
\end{tabular}

Keterangan: Huruf yang berbeda di belakang angka menunjukkan perbedaan yang nyata pada $\alpha 0,05$

Sineresis terkecil setelah penyimpanan beku terjadi pada gel komposit dengan proporsi GP-X 80/20, baru diikuti gel komposit proporsi 20/80 dan 60/40. Selain WBC awal yang rendah, zona hubung dan jaringan 3 dimensi yang terbentuk pada gel $80 / 20$ lebih sedikit dan mengakibatkan penurunan air yang terperangkap dalam matriks dan juga penurunan sineresis.

\section{Morfologi Gel pada Awal dan Setelah Penyimpanan}

Glukomanan konjac bersinergi dengan xantan membentuk gel (Fitzpatrick dkk., 2013; Liang dkk., 2011; Paradossi dkk., 2002). Ikatan silang terjadi antara xantan dengan xantan dan glukomanan dengan xantan. Xantan terdispersi sebagai mikrogel yang bergabung dengan lemah. Glukomanan berpenetrasi ke dalamnya dan berikatan silang dengan xantan menghasilkan zona hubung. Ikatan silang yang cukup ini akan mengubah gel lemah menjadi gel yang kuat (Morris (2007).
Pada Gambar 2F dapat dilihat glukomanan 1\% yang dilarutkan sampai homogen akan membentuk sol. Morfologi sol nampak berupa lapisan kontinyu tanpa terbentuk ruang tiga dimensi. Sedangkan pada gel komposit GP-X (Gambar 2A-D), asosiasi glukomanan dengan xantan membentuk zona hubung yang menghasilkan struktur jaringan tiga dimensi dimana air terperangkap di dalamnya membentuk ikatan hidrogen.

Peningkatan proporsi GP-X yang lebih besar sampai 60/40 menyebabkan jumlah struktur tiga dimensi (pori) bertambah banyak dengan ukuran semakin kecil, namun zona hubung menjadi lebih pendek dengan densitas yang lebih rendah (Gambar 2A-D). Bertambahnya zona hubung tersebut menyebabkan peningkatan daya kohesif, namun zona hubung yang lebih pendek dan densitas rendah menyebabkan penurunan hardness, chewiness, gumminess dan peningkatan persentase deformasi. Sedangkan, pada gel komposit glukomanan 80/20, jaringan ruang 3 dimensi berukuran lebih besar dan memanjang, namun zona penghubung dan jumlah ruang 3 dimensi berkurang signifikan karena kelebihan proporsi glukomanan tidak akan membentuk gel tetapi menjadi fase kontinyu berupa sol glukomanan. Perubahan ini tidak hanya menyebabkan springiness menurun secara signifikan, tetapi juga pada daya kohesif, chewiness, gumminess, dan hardness, sehingga deformasi meningkat (Gambar 2A-E).

Glukomanan dan xantan bersinergi dalam pembentukan gel. Glukomannan yang tidak tersubstitusi asetil berasosiasi dengan xantan membentuk gel. Brownsey dkk. (1988) menemukan bahwa interaksi antara GK dengan xantan dalam bentuk disorder terjadi pada suhu di atas transisi heliks-koil. Sebaliknya, Fitzsimons dkk., (2008); Goycoolea dkk., (1995) mendapatkan bahwa asosiasi tidak membutuhkan xantan dalam bentuk disorder. Namun gel akan terbentuk lebih kuat setelah dipanaskan $95{ }^{\circ} \mathrm{C}$, di atas suhu transisi helikskoil, lalu didinginkan ke $20{ }^{\circ} \mathrm{C}$ dibandingkan pada suhu yang tepat atau di bawah suhu transisi konformasi xantan (Annable dkk., 1994). Xantan yang terdeasetilasi akan menghasilkan gel yang lebih kuat dari xantan native (Fitzpatrick dkk., 2013; Tako, 1992). Deasetilasi menyebabkan xantan bebas dari asosiasi intramolekuler dengan gugus asetil sehingga interaksi intermolekul lebih kuat (Tako, 1992).

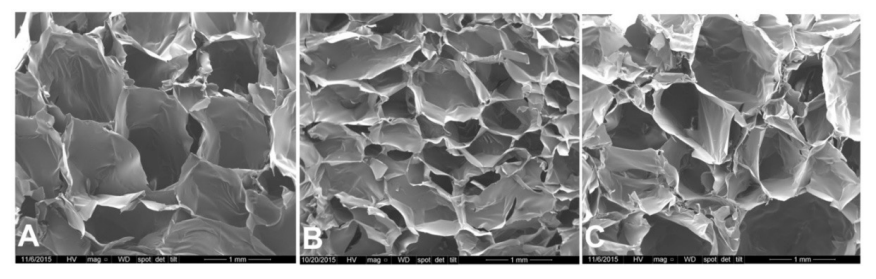

Gambar 3. SEM morfologi pori komposit gel glukomanan proporsi glukomanan porang xantan 20/80 sebelum penyimpanan (A), setelah 24 hari penyimpanan dingin (B), dan beku (C) 
Interaksi antara glukosa xantan akan berlangsung dengan glukosa GK yang tersusun berurutan sebanyak $\geq 6$ gula (Mao dkk., 2012; Gooycoolea dkk., 1995). Rantai-rantai samping molekul xantan berperan dalam interaksi sinergi dengan kerangka utama GK. Interaksi mungkin terjadi antara hemiasetal atom oksigen pada rantai samping manosa xantan dengan gugus hidroksil pada C-2 residu manosa glukomanan dengan ikatan hidrogen. Kation $\mathrm{K}^{+}$pada gugus karboksil intermediat asam glukuronat pada rantai samping xantan juga berperan dalam interaksi dengan atom oksigen hemiasetal backbone molekul glukomanan yang dekat dengan gaya elektrostatis (Tako,1992; 1993).

Pada Gambar 3B, pori gel komposit GP-X setelah penyimpanan pada suhu dingin 24 hari nampak lebih kecil, sebaliknya setelah penyimpanan beku, beberapa pori kelihatan lebih besar (Gambar 3C). Selama penyimpanan dingin, ikatan gel mengalami kontraksi semakin dekat dan menyebabkan terjadinya peningkatan sineresis. Namun, peningkatannya lebih kecil dibandingkan dengan penyimpanan beku. Sedangkan pada penyimpanan beku, meskipun WBC meningkat (Tabel 1), pengembangan volume air menjadi kristal es memperbesar pori morfologi gel komposit dan menyebabkan peningkatan sineresis (Tabel 2).

\section{KESIMPULAN}

Sinergi pembentukan gel komposit GP-X optimal terjadi pada ratio 20/80. Intermolekul GP-X tersebut membentuk zona hubung yang panjang, densitas tinggi dan kuat sehingga gel proporsi 20/80 memiliki hardness, chewiness, dan gumminess paling tinggi dengan derajat deformasi dan sineresis paling rendah serta daya kohesif yang sedang.

Meskipun belum mengalami sineresis selama penyimpanan dingin, gel komposit GMP-X setelah 24 hari penyimpanan dingin mengalami kontraksi dan penurunan mutu dengan indikasi terjadi penurunan daya kohesif, chewiness, hardness, dan gumminess. Peningkatan WBC pada proporsi GP-X lebih tinggi menyebabkan gel lebih stabil pada penyimpanan beku. Pembesaran pori akibat pengembangan volume air yang terperangkap saat perubahan menjadi kristal es menyebabkan peningkatan sineresis, gel lebih padat dan peningkatan hardness, chewiness, dan gumminess.

\section{UCAPAN TERIMA KASIH}

Ucapan terima kasih diberikan kepada Kementrian Riset, Teknologi dan Pendidikan Tinggi Republik Indonesia ini yang telah memberikan bantuan dana untuk sebagian penelitian ini pada Program Hibah Pasca Sarjana pada tahun anggaran 2014.

\section{DAFTAR PUSTAKA}

Alonso-Sande, M., Teijeiro-Osorio, D., RemuñánLópez, C. dan Alonso, M.J. (2009). Glucomannan, a promising polysaccharide for biopharmaceutical purposes. European Journal of Pharmaceutics and Biopharmaceutics 72(2): 453-462.

Al-Ghazzewi, F.H., Kanna, S., Tester, R.F. dan Piggott, J. (2007). The potential use of hydrolyzed konjac glucomannan as a prebiotic. Journal of the Science and Food Agriculture 87: 1758-1766.

Akesowan, A. (2012). Syneresis and texture stability of hydrogel stability of hydrogel complexes containing konjac flour over multiple freeze-thaw cycles. Life Science Journal 9(3): 1367-1367.

Akesowan, A. (2002). Viscosity dan gel formation of konjac flour from Amorphophallus onchopyllus. AU Journal of Technology 5(3): 139-146.

Annable, P., William, P.A. dan Nishinari, K. (1994). Interaction in xanthan-glucomannan mixtures dan influence of electrolyte. Macromolecules 27: 4204-4211.

Behera, S.S. dan Ray, R.C. (2016). Konjac glucomannan, a promising polysaccharide of Amorphophallus konjac K.Koch in health care. International Journal of Biological Macromolecules 92: 942-956.

Brenner, T., Tukivine, R., Fang, Y., Matsukawa, S. dan Nishinari, K. (2015). Rheology of highly elastic iota/ kappa-carragenan/xanthan/konjac glucomannan gels. Food Hydrocolloids 44: 136-144.

Brownsey, G.J., Chairns, P., Miles, M.J. dan Morris, V.J. (1998). Evidence for intermolecular binding between xanthan and the glucomannan konjac mannan. Carbohydrate Research 176: 329-334.

Chen, J., Li, J. dan Li, B. (2011). Identification of molecular driving forces involved in the gelation of konjac glucomannan: effect of degree of deacetylation on hydrophobic association. Carbohydrate Polymers 86: 865-871.

Cheng, L.H., Karim, A. Abd. dan Seow, C.C. (2007). Effects of acid modification on physical properties of konjac glucomannan (KGM) films. Food Chemistry 103: 994 1002.

Cheng, L.H., Karim, A. Abd., Norziah, M.H. dan Seow, C.C. (2007). Modification of microstructural and physical properties of konjac glucomannan-based films by alkali and sodium carboxymethylcellulose. Food International Research 35: 829-836. 
Chua, M., Baldwin, T.C., Hocking, T.J. dan Chan, K. (2010). Traditional uses and potential health benefits of Amorphophallus konjac K. Koch ex N.E. Br. Journal of Ethnopharmacology 128: 268-278.

deMan, J.M. (2000). Principles of Food Chemistry. $3^{\text {th }}$ Edn. An Aspen Publication.

Fitzpatrick, P., Meadows, J., Ratcliffe, I. dan William, P.A. (2013). Control of the properties of xanthan/ glucomannan mixed gels by varying xanthan fine structure. Carbohydrate Polymers 92: 1018-1025.

Fitzsimon, S.M., Tobin, J.Y. dan Moris, E.R. (2008). Synergistic binding of konjac glucomannan to xanthan on mixing at room temperature. Food Hydrocolloids 22: $36-46$.

Gao, S. dan Nishinari, K. (2004). Effect of degree of acetylation on gelation of konjac glucomannan. Biomacromolecules 5: 175-185.

Goycoolea, F.M., Richardson, R.K., Morris, E.R. dan Gidley, M.J. (1995). Stoichiometry dan conformation of xanthan in synergistic gelation with locust bean gum or konjac glucomannan: evidence for heterotypic binding. Macromolecular 28: 8308-8320.

He, P., Luo, X., Lin, X. dan Zhang, H. (2012). The rheological properties of konjac glukomannan (KGM) solution. Material Science Forum 724: 57-60.

Herranz, B., Tovar, C.A., Solo-de-Zaldivar, B. dan Borderias, A.J. (2013). Influence of alkali dan temperature on glucomannan gels at high concentration. LWT-Food Science dan Technology 51: 500-506.

Hosogoe, M., Hashimoto, K., Kawauchi, Y. dan Kamifukuoda. (1992). Flavoured konyaku composition, process for preparing same dan food product containing same. United States Patent, No. 5,173,321. December, 22.

Jimenez-Colmenero, E., Cofrades, S., Herrero, A.M., Fernandes-Martin, F., Rodriguez-Salaz, L., Ruiz-Salas, M.T. dan Ruiz-Capillas, C. (2012). Konjac gel fat analogue for use in meat products: comparison with pork fats. Food Hydrocolloids 26: 63-72.

Jimenez-Colmenero, E., Cofrades, S., Herrero, A.M., Solas, M.T. dan Ruiz-Capillas, C. (2013). Konjac gel for use as potential fat analogue for healthier meat product development: effect of chilled dan frozen storage. Food Hydrocolloids 30: 351-357.

Kohyama, K. dan Nishinari, K. (1997). New application of konjac glucomannan as a texture modifier. Japan Agricultural Research Quarterly 31: 301-306.
Liang, S., Li, B., Ding, Y., Xu, B.L., Chen, J., Zhu, B., Ma, M.H., Kennedy, J.F. dan Knill, C.J. (2011). Comparative investigation of the molecular interactions in konjac gum/hydrocolloid blends: Concentration addition method (CAM) versus viscosity addition method (VAM). Carbohydrate Polymers 83: 1062-1067.

Lin, Kuo-Wei. dan Huang, Chiu-Ying. (2008). Physicochemical dan textural properties dan textural properties of ultrasound-degraded konjac flour dan their influences on the quality of low-fat Chinese-style sausage. Meat Science 79: 615-622.

Maeda, M., Shimahara, H. dan Sugiyama, N. (1980). Detailed examination of the branched structure of konjac glucomannan. Agricultural and Biological Chemistry 44: $245-250$.

Mao, Ching-Feng, Klinthong, W., Zeng, Yuan-Chang, dan Chen, Cheng-Ho. (2012). On the interaction between konjac glucomannan dan xanthan in mixed gels: an analysis based on the cascade model. Carbohydrate Polymers 89: 98-103.

Morris, V.J. (2007). Polysaccharides: their role in food structure. Dalam: Mc.Clements, D.J. (Ed.). Understanding dan controlling the microstructure of complex foods, hal. 3-39. Woodhead Publishing Limited.

Nishinari, K. dan Takahashi, R. (2003). Interaction in polysaccharide solutions and gels. Current Opinion in Colloid and Interface Science 8: 396-406.

Ojima R., Makabe, T., Prawitwong, P., Takahashi, R., Takigami, M. dan Takigami, S. (2009). Rheologi property of hydrolyzed konjac glucomannan. Transaction of the Materials Research Society of Japan 34(3): 477-480.

Paradossi, G., Chiessi, E., Barbiroli, A. dan Fessas, D. (2002). Xanthan dan glucomannan mixtures: sinergistic interactions dan gelation. Biomacromolecules 3: 498504.

Ramirez, J.A., Uresti, R.M., Velazquez, G. dan Vazquez, M. (2011). Food hydrocolloids as additives to improve the mechanical and functional properties as fish products: a review. Food Hydrocolloids 25: 1842-1852.

Shen, D., Wan, C. dan Gao, S. (2009). Molecular weight effects on gelation and rheological properties of konjac glucomannan-xanthan mixtures. Journal of Polymer Science 48: 313-321.

Takigami, S. (2000). Konjac mannan. Dalam: Phillips, G.O. dan Williams, P.A. (Ed.). Handbook of Hydrocolloids, hal. 413-424. Cambridge: Wood Publishing. 
Tatirat, C., Charoenrein, S. dan Kerr, W.L. (2011). Physichochemical properties of extrusion-modified konjac flour. Carbohydrate Polymer 87: 1545-1551.

Tako, M. (1993). Binding sites for mannose-specific interaction between xanthan and galactomannan, dan glucomannan. Colloid dan surfaces B, Biointerfaces 1: 125-131.

Tako M. (1992). Syntergistic interaction between xanthan dan konjac glucomannan in aqueous media. Bioscience dan Biotechnology Biochemistry 56(8): 1188-1192.

Tester, R.F. dan Al-Ghazzewi, F.H. (2009). Utilization of glucomannan for health. Dalam: Clarence, S.H. (Ed). Food Hydrocolloids, Characteristics, Properties, dan Structures, hal. 348 Nove Science Publishers, Inc.

Tester, R.F. dan Al-Ghazzewi, F.H. (2013). Mannans and health, with a special focus on glucomannans. Food Research International 50(1): 384-391.

Wen, X., Wang, T., Wang, Z., Li, L. dan Zhao, C. (2008). Preparation of konjac glucomannan hydrogels as DNAcontrolled release matrix. International Journal of Biological Macromolecules 42: 256-263.

Williams, P.A., Day, D.H., Langdon, M.J., Phillips, G.O. dan Nishinari. (1991). Synergistic interaction of xanthan gum with glucomannan dan galactomannans. Food Hydrocolloids 4(6): 489-493.
Xiong, G., Cheng, W., Ye, L., Du, X., Zhou, M. dan Lin, R. (2009). Effect of konjac glucomannan on physic chemical properties of myofibrillar protein and surimi gels from grass carp (Ctenopharryngodon idella). Food Chemistry 116: 413-418.

Yanuriati, A., Marseno, D.W., Rochmadi dan Harmayani, E. (2017). Characteristics of glucomannan isolated from fresh tuber of porang (Amorphophallus muelleri Blume). Carbohydrate Polymers 156: 56-63.

Yin, W., Zhang, H., Huang, L. dan Nishinari K. (2008). Effect of the lyotropic series salts on the gelation of konjac glucomannan in aqueous solutions. Carbohydrate Polymers 74: 68-78.

Zhang, H., Yoshimura, M., Nishinari, K., William, M.A.K., Foster, T.J. dan Norton, I.T. (2011). Gelation behavior of konjac glucomannan with different molecular weights. Biopolymers 59: 38-50.

Zhang, Y.Q., Xie, B.J. dan Gan, X. (2005). Advance in the applications of konjac glucomannan dan its derivatives. Carbohydrate Polymers 60: 27-30. 